\title{
PRIESTS OF THE GROVES (RE)CREATING ANCIENT RITES IN THE AUGUSTAN CULTURE
}

\begin{abstract}
Summary: The past was reinvented in the Augustan culture through true or fictitious archaic cults, and this paper deals with some priesthoods related to sacred groves, or with the iconography of sacred luci appearing in some coins. Some examples are considered, such as an inscription from Peñaflor/Celti (Seville) mentioning a pontufex nemoris, a reference to the eques P. Aelius Marcellus, who appears in an epigraph from Umbria not only as Laurens Lavinas but also as flamen lucularis, or some images that document the reception of ancient notions of the sacred groves in the Roman provinces, as some recurrent types in the coins of Juba II of Mauritania depicting trees with an altar between them and the legend Lucus Augusti show. The question of whether these manifestations are merely expression of loyalism to the Emperor or whether they might imply some kind of local tradition is also posed.
\end{abstract}

Key words: lucus, nemus, sacred groves, Gabii

"Should you be offered a view of a rainforest abundant in ancient trees of exceptional height, making it difficult to contemplate the sky due to the thickness of the interweaving branches, the size of that jungle, the solitude of the area and the wonderful impression of such dense continuous shade in the countryside will awaken in you a belief in the divine".

This text by Seneca strongly reflects the sanctity inherent in natural spaces and, especially, in the sacred groves, which are shown in various ancient cultures as privileged places in which to commune with the divine. ${ }^{2}$ A feeling of religious mystery

${ }^{1}$ Sen. Ep. 4. 41. 3: Si tibi occurrerit vetustis arboribus et solitam altitudinem egressis frequens lucus et conspectum caeli ramorum aliorum alios protegentium summovens obtentu, illa proceritas silvae et secretum loci et admiratio umbrae in aperto tam densae atque continuae fidem tibi numinis faciet.

2 In other words, as "sanctuaries" - understanding this space to be communem deis et hominibus / teujtoni[o] $n$, as cheerfully defined in the Latin-Gallic bilingual inscription in Vercelli (LEJEUNE, M.: Enclos sacré dans les épigraphies indigenes d'Italie. In DE CAZANOVE, O. - SCHEID, J. [éd.]: Les bois sacrés. Actes du Colloque International organisé par le Centre Jean Bérard et l'École Pratique des Hautes Études (Ve section), Naples, 23-25 Novembre 1989. Naples 1993, 93-101, here 99-100). 
pervaded the animus of any who entered a sacred grove, whose exceptional character illustrated the presence of a god, a vis or a numen. As Ovid said (Fasti 3. 296) about the Aventine when it was a hill covered in black oaks: quo posses viso dicere: numen inest. Property or residence of a god who manifests through oracles, ${ }^{3}$ the lucus (latin term for sacred grove) did not belong to the human world. ${ }^{4}$

Both Seneca and Pliny (NH 12.3-5) admired the majesty of the sacred groves as the dwelling place of the divinity prior to inhabiting man-made sanctuaries. This memory of the primeval sanctuary in the grove is reflected in passages such as those of Strabo wherein he showed that the poets referred to all sanctuaries as "sacred groves" even when they were devoid of vegetation - such as the examples cited of the Poseidon sanctuary in Onchestos and that of Achilles at the mouth of the Dnieper river (Strabo 9. 2. 33 and 6. 3. 19).

The purpose of this paper is to examine some significant cultural evidence from the Augustan era in wooded areas. I will focus on a few examples.

\section{LUCUS AUGUSTI}

A key element in the first extension of the imperial cult in the provincia Tarraconensis and, specifically, in the conventus - divisions of the province - of the North West ${ }^{5}$ is the founding of Lucus Augusti by Paulus Fabius Maximus, one of the amici of the Prince (Tac. Ann. 1. 5; Ovid. ex Pont. 3. 3, 4. 6, etc.). As with the other conventual capitals of the Northwest, the founding of Lucus Augusti, took place within the

${ }^{3}$ BRIQUEL, D.: Les voix oraculaires. In Les bois sacrés (n. 2) 77-91.

${ }^{4}$ Based on texts by different Greco-Latin writers (such as Lucian of Samosata, De sacrificiis 1011), the 19th century historiography - especially that of the German Romantics - considered that the groves would have constituted the fundament of the sanctuary. The theories about the cult of "sacred nature" (from Creuzer and Grimm, to Böticher and Preller) are based on the existence of an elemental, purifying, nurturing, life-sustaining and enthusing force (das Dämonische) which manifested itself in the silence of the groves, at the peaks of the mountains, in the whispering of the streams or springs or in the grottoes. However, as Scheid rightly observed, unlike the Romantics, the ancients did not feel a mystical ecstasy towards nature, but rather a respectful fear, and this was towards the abode of the gods and not the gods themselves (SCHEID, J.: Lucus, nemus. Qu'est -ce qu' un bois sacré? In Les bois sacrés (n. 2) 13-22, here 17, 19-20); contra, upholding the possibility of dendrolatry, COARELLI, F.: I luci del Lazio: la documentazione archeologica. In Les bois sacrés (n. 2) 45-52, here 46. The tree, with the pinakes and offerings hanging from its branches, constitutes one of the indicators of the sanctuary in Greek pottery (MYLONOPOULOS, J.: Natur als Heiligtum - Natur im Heiligtum. Archiv für Religionsgeschichte 10 [2008] 5183 , here 62 , fig 3, and refs.), and was one of the characteristic tropia in "sacro-idyllic" landscape of the Romano-Hellenistic period (Vitruv. 7. 5. 2; Plin. NH 35. 116; SCHEFOLD, K.: Origins of Roman landscape painting. The Art Bulletin 42 [1960] 87-96, here 90). Consideration of "nature as sanctuary" changed to the incorporation of "nature in the sanctuaries" artificially built by man (MYLONOPOULOS 60-62). In the Hellenic world, the alsos is a naturally limited place within the countryside where the divinity manifests with particular intensity - "a natural and divine manifestation of a mediation place between two worlds" (BONNECHERE, P.: The place of the sacred grove (alsos) in the mantic rituals of Greece: the example of the Oracle of Trophonios at Lebadeia (Boeotia). In CONAN, M. [ed.]: Sacred Gardens and Landscapes: Ritual and Agency. Washington 2007, 17-41, here 41).

${ }^{5}$ MARCo SimÓN, F.: Los inicios del culto imperial en Hispania en época augústea. In La Hispania de Augusto. Congreso internacional, Madrid 7-9 abril 2014, forthcoming. 
context of the second coming of Augustus to Hispania in $15 \mathrm{BC}$. The same Fabius Maximus is mentioned on a cylindrical altar of Bracara Augusta conserved in the museum in Guimarâes (CIL II 2411; EE VIII 280). Three further altars found in Lucus Augusti (Lugo) record this character as V(rbis) C(onditori) A(ugusto) M(onumentum) Caesari Paullus Fabius Maxumus Legat(us) Caesaris ("Monument to Augustus, founder of the city, Paullus Fabius Maximus, legate of Caesar, makes this dedication to Caesar"). ${ }^{6}$

We have epigraphic confirmation of the existence of priests in relation to the sacred grove for which Lucus Augusti was named. This is in the form of an inscription conserved in Astorga, León (ancient Asturica Augusta, capital of the Conventus Asturum), which mentions a sacerdos Romae et Augusti ad Lucum Augustum who later became a provincial flamen in Citerior. ${ }^{7}$ In other words, this was a priest of the imperial cult who had duties in the sanctuary from which the city derived its name.

In addition, in Gallia Narbonensis two further Lucus Augusti are documented (CIL XIII 5207, 6978, 7011) in present day Aix-en-Diois and Luc-en-Diois (in the département of Drôme, in the Rhône-Alpes region, the lands of the ancient Vocontii). Without leaving North-West Hispania, another name of interest is Lucus Asturum, i.e. "the sacred grove of the Asturs" (Lugo de Llanera, Asturias). ${ }^{8}$

In some cases, a town formed around these sacred luci, giving rise in various parts of the Roman world to that series of cities known as Lucus Aquilonensis, Lucus Bormani, (Diano Marina, in Liguria), Lucus Feroniae, Lucus Fucens, Lucus Angitiae, etc. Octavius himself founded the Colonia Iulia Felix Lucoferensis, and it is possible that the Roman interpretatio of the sanctuary of the Lusitanian goddess Ataegina in Alcuéscar (Caceres) as Lucus Feroniae - the name with which it appeared in later Gromatican references ${ }^{9}-$, arose in the Augustan period.

In Hispania, there were two types of sacred groves: ${ }^{10}$ the indigenous lucus - very similar, just as in Gallia, to the sacred groves of Italy, as is the case of the Botorrita bronzes $^{11}$-, and the lucus imported by the Romans. Three seemingly common factors influenced the genesis and development of these inhabited locales: religion, commerce (market/fair), and road network location. Thus, it is logical to imagine that these groves would have originally had an indigenous law that regulated the first two features and that this was assumed or adapted by the Roman authorities. Some of these sites evolved

${ }^{6}$ Rodríguez Colmenero, A.: La Fonte do Ídolo, los demás ídolos de la fuente y... no sólo. In Rodríguez Colmenero, A. (ed.): Bracara Augusta Romana. Xunta de Galicia, Santiago de Compostela 2012, 65-85, here 84-85.

${ }^{7}$ CIL II 4255 = EDCS-05502010: ] Memmius [3] / Anie(n)s(i) Barbarus / sacerdos Romae et Aug(ustorum) / ad Lucum Aug(usti) / flamen provinciae Hispa/niae citerioris / trib(unus) mil(itum) leg(ionis) I Italicae an(norum) LVIIII h(ic) s(itus) e(st). See RODRÍGUEZ COLMENERO, A. (coord.): Lucus Augusti. I. El amanecer de una ciudad. A Coruña 1996, 296 and 298, n. 156.

${ }^{8}$ Ptol. Geog. 2. 6. 28; Ravenn. 320. 16.

${ }_{9}^{9}$ García-Bellido, M. P.: Lucus Feroniae Emeritensis. AEspA 74 (2001) 53-71.

${ }^{10}$ FERNÁNDEZ NieTO, F. J.: Encuesta sobre las regulaciones de los luci hispanos. Serta Palaeohispanica J. de Hoz, Palaeohispanica 10 (2010) 537-550.

${ }^{11}$ DE Bernardo STEMPEL, P.: La ley del 1er Bronce de Botorrita: uso agropecuario de un encinar sagrado. In Burillo Mozota, F. (ed.): VI Simposio sobre Los Celtíberos: Ritos y Mitos. Daroca, 27-29 de noviembre de 2008. Zaragoza 2010, 123-145. 
towards stable urban locations; by contrast, other luci that also had their lex as they were located in particularly isolated areas (with little rural Romanisation) did not experience this process and maintained their parochialism, isolated within the lands of a colony or municipality. ${ }^{12}$

The link between the sacred grove and Augustus - evident in the Hispanic and Gallic examples mentioned - is equally visible in the numismatic coinage. In particular, there is a series of coins minted for Juba II, the erudite King of Mauritania who was a contemporary of Augustus and reigned from $25 \mathrm{BC}$ to $24 \mathrm{AD} .^{13}$ The coins in question feature a series of types that are recurrent in the key imperial cult locations, for which they constituted a form of expressing loyalty to the Prince by the monarch and the Mauritanian people. In addition to a temple with the legend AVGVSTI on the pediment, ${ }^{14}$ of special interest here are those that feature an altar with the legend LVCVS AVGVSTI accompanied by trees which would have been representing the grove in which the altar would be located. These types seem to refer to Caesarea, where the temple and sacred grove were probably located. ${ }^{15}$

It is well known the priesthood of the rex Nemorensis mentioned by Ovid (Fast. 3. 309 ss.), Suetonius (Gai. 35), Strabo (5. 3. 12), Virgil (Aen. 7. 761 ff.) and Pausanias (2. 27. 4) served as the basis for that literary monument that is "The Golden Bough" by J. G. Frazer. We conserve an image on the reverse of the P. Accoleius Lariscolus denarius (datable to $43 \mathrm{BC}$ ), which depicts the triple Diana with an orderly series of 5 cypresses in the background, in what is probably the best known sacred grove of the Ancient World. ${ }^{16}$

According to information from Suetonius (Aug. 43), Augustus organised a naval battle near the Tiber "where today lie the sacred groves of the Caesars". This nemus Caesarum would have had the characteristics of a funeral garden dedicated to Gaius and Lucius, as Spannagel rightly states, ${ }^{17}$ and it would have recalled the original connection between Aeneas and the sacred grove. Aeneas had erected a monument to his father Anchises in Lavinium in a grove (Dion. Hal. 1. 64. 5; Sil. Pun. 8. 39), the lucus Solis Indigetis (Plin. NH 3. 56) which was the sacred grove from which Aeneas disappeared - as noted in the Elogium by the Aeneas group found in Pompeii and in Merida. ${ }^{18}$

\footnotetext{
${ }^{12}$ FERNÁNDEZ NieTO (n. 10).

${ }^{13}$ Coltelloni-Tranoy, M.: Le royaume de Mauritanie sous Juba II et Ptolémée (25 av. J.-C. 40 ap. J.-C.). Paris 1997.

${ }^{14}$ Alexandropoulos, J.: Les monnaies de l'Afrique Antique (400 av. J.-C. - 40 ap. J.-C.). Toulouse 2000, reverse F1-F5.

${ }^{15}$ COLTElloni-Tranoy (n. 13) 190; Suspène, A.: L'apport de la documentation numismatique à l'étude des Foreign Clientelae: le cas de Juba II de Maurétanie. In JEHNE, M. - PINA POLO, F. (eds.): Foreign Clientelae in the Roman Empire: A Reconsideration [Historia Einzelschriften, Bd. 238]. Stuttgart 2015, 185-208.

${ }^{16}$ Ampolo, C.: Boschi sacri e culti federali: l'esempio del Lazio. In Les bois sacrés (n. 2) 159167 , here 162, fig. 1.

${ }^{17}$ Spannagel, M.: Exemplaria Principis. Untersuchungen zu Entstehung und Ausstattung des Augustusforums. Heidelberg 1999, 24, n. 61.

${ }^{18}$ SPANNAGEL: Exemplaria Principis (n. 17), 168 and notes 500 and 692.
} 


\section{A PONTUFEX NEMORIS IN BAETICA}

Of special interest in relation to priesthoods in sacred groves in the Augustan era is a funerary inscription, recently published by Armin Stylow, from Peñaflor (Seville), the ancient Celti, a toponym which just like the monetary legend Celtitani clearly alludes to the classical ethnonym of the Celts. ${ }^{19}$

[Q(uintus) - - -]rarius Q(uinti et) C(ai) l(ibertus) $\cdot$ Dae-
[s]a m[onume] ntum $\cdot$ fecit
$\cdot$ se [vivo] sibi $\cdot$ heic est
sepult[us po]ntufex
nemoris Daesa
Dis Manibus
bonus $\cdot$ homo $\cdot$ et $\cdot$ ego
$($ CIL II 7.745$)$.

The chronology of the inscription, as demonstrated by Armin Stylow ${ }^{20}$ is from a very early period - the final decades of the 1 st century BC. This dating is based on both palaeographic criteria and onomastics of the deceased, which mentions his situation as a freedman of two masters (Quintus and Gaius) - a practice that disappeared in the reign of Augustus. Other features point to that early chronology, such as certain spellings (the archaic heic instead of hic and also pontufex for pontifex - though this spelling would remain far longer) or the type of stone, a dark limestone from Sierra Morena (the material typically used in this area for epigraphs from the Augustan era and prior to the widespread introduction of marble). The formula Dis Manibus, whose use even in Rome does not precede the second half of the $1^{\text {st }}$ century $\mathrm{BC}$, provides the oldest testimony to this in the Peninsula and, possibly, one of the oldest in the Empire. Daesa is a cognomen that is unattested by other inscriptions but, presumably, is of indigenous Celtic origin, like the coins reverses with the wild boar.

The identity of this Quintus Daesa is defined by the performance of a religious function unknown until the date on the epigraph: he is a "pontiff of the grove", pontufex nemoris. This second element in genitive is the specific term to allude to the sacred grove as a place of sanctuary - nemus and not lucus. Unlike the lucus (a dark and wild grove), the nemus would be a humanised grove, more in concert with the

19 The coins minted - datable to the first half of the 2 nd century BC - show, in common with the legend CELTITAN(I), a crowned male head with a laurel and mantle on the front, but the reverse is more significant with a wild boar running to the right (GARCÍA-BELLIDO. M. P. - BLÁZQUEZ, C.: Diccionario de cecas y pueblos hispánicos con una introducción a la numismática antigua de la Península Ibérica. Volumen I: Introducción. Volumen II: Catálogo de cecas y pueblos que acuñan moneda. Madrid 2001, II 104) that, while it may allude to the mines of the city, constitutes an iconographic element that is characteristic of the Celtic peoples. The wild boar was extremely important in the imagination of the Celts; proof of this can be found in its ubiquity in the iconography of the Iron Age and in the Roman-Celtic context (GREEN, M.: Symbol and Image in Celtic Religious Art. London 1989, 139-141).

${ }^{20}$ STYLOW, A. U.: Una inscripción enigmática, reencontrada. Almenara 30 (2010) 54-59. 
Greek conditions of alsos ${ }^{21}$ - as is made clear in a passage from the grammarian Servius: "A lucus is a group of trees sacred in nature, a nemus a series of well ordered trees and a silua a thick unkempt grove" (Serv. auct. Aen. I 310). ${ }^{22}$ Within this nemus, there would be the sacred clarity, the lucus (whose radical is related to lux), ${ }^{23}$ assimilated to a templum. ${ }^{24}$ However, this difference in character, undoubtedly operative in its origin, would be attenuated over time: from the evidentiary inscriptions ${ }^{25}$ the fact emerges that the lucus can be the same sanctuary constructed artificially. ${ }^{26}$

In any case, this original distinction between lucus and nemus may be of interest when explaining the religious role held by Daesa: pontufex nemoris. The pontiff, the socially useful religious magistrate par excellence compared to the other priesthoods, ${ }^{27}$ would be the person who would undertake the consecration of the nemus, which would definitively entail the link between the human conurbation and the divine beyond which can be clearly seen in other spheres such as the Brahmanic India. $^{28}$

The link between the Roman priesthoods and the sacred woods inherent to Daesa appears confirmed in several specific cases cited by the sources, beginning obviously with that of the fratres Arvales and the Dea Dia grove. ${ }^{29}$ But there is a more specific connection between the pontiffs and the sacred groves that is of interest here. The emperor Claudius entrusts the pontiffs to undertake the purification rituals in the nemus Dianae in Aricia, and this reference can serve to understand why this priest-

${ }^{21}$ Contrary to the lucus as locus numinosus, a permanent space of divinity strictly separated from the world of men, the oracular Greek alsos is the place where God and man meet in an ecstatic divination (GRAF, F.: Bois et oracles en Asie Mineure. In Les bois sacrés [n. 2] 23-29, here 29).

${ }^{22}$ Serv. Auct. Aen. I 310: interest... inter nemus et siluam et lucum; lucus enim est arborum multitudo cum religione, nemus uero composita multitudo arborum, silua difusa et inculta.

${ }^{23}$ For such an etymology, related to lux, see Thesaurus Linguae Latinae, s.v. lucus; ERNOUT, A. Meillet, A.: Dictionnaire étymologique de la langue latine. Paris $1959^{4}$, s.v. lucus.

${ }^{24}$ Conrelli, F.: Munigua, Praeneste e Tibur. I modelli laziali di un municipio della Betica. Lucentum 6 (1987) 91-100; COARELLI: I luci (n. 4).

${ }^{25}$ Details in COARELli: I luci (n. 4) 46-47.

${ }^{26}$ What could be inferred from the dedication of the federal sanctuary in Nemi issued by Cato (Orig. fr. 58 Peter: Lucum Dianium in nemore Aricino Egerius Baebius Tusculanus dedicavit dictador Latinus. Hi populi communiter: Tusculanus, Aricinus, Lanuvinus, Laurens, Coranus, Tiburtis, Pometinus, Ardeatis Rutulus), with the text from an archaic inscription of around $500 \mathrm{BC}$ according to AMPOLO, C.: Ricerche sulla lega Latina. II. La dedica di Egerius Baebius (Cato, fr. 58 Peter). Parola del Passato 38 (1983) 321-326. See also Ov. Met. V 265; Ov. Fasti II 165. On the sanctuary of Nemi see now BRANCONI, P. - CoARelli, F. - Diosono, F. - GHINI, G.: Il santuario di Diana a Nemi. Le terraze e il ninfero. Scavi 1989-2009. Roma 2014.

${ }^{27}$ PORTE, D.: Le prêtre à Rome. Paris 1995, 131-143.

${ }^{28}$ The opposition between city and woods, between the space for mankind and that for the Beyond and the gods, has been commendably identified in Brahmanic India by CH. MALAMOUD (Village et fôret dans l'idéologie de l'Inde brahmanique. In MALAMOUD, CH. [éd.]: Cuire le monde. Rite et pensée dans l'Inde ancienne. Paris 1989, 93-114, here 101), and this duality seems to be similarly considered in Rome (SCHEID: Lucus [n. 4] 20).

${ }^{29}$ SCHEID, J.: Recherches archéologiques á La Magliana. Commentarii Fratrum Arvalium qui supersunt. Les copies épigraphiques des protocoles annuels de la confrérie arvale (21 av. - 304 ap. J.-C.). Roma 1998. 
hood is mentioned on the Peñaflor/Celti gravestone of Daesa and not the flamen, which in Baetica served to designate the priests of the imperial cult.

There are not many literary mentions of sacred groves. The most famous reference is assuredly that of one located near Marseilles that Caesar ordered cut down at the beginning of the Civil War (Lucan, Phars. 3. 399-449 ${ }^{30}$ ). Not far from Cádiz, a lucus called Oleastro (Plin. NH 3. 15) was found, ${ }^{31}$ and in the area of El Trampal (Alcuéscar, Cáceres), in Celtic Baeturia, there was another sacred grove, which was called lucus Feroniae by later surveyors. Assuredly, the grove belonged to the land mass of the Emerita Augusta colony, and here the indigenous goddess Ataecina (assimilated to Proserpina) would have been worshipped. ${ }^{32}$

The antiquarian interest that Daesa's priesthood denotes is shared by other measures of the period. Thus, the self-portrait of Caligula as rex Nemorensis (Suet. Gai. 35) ${ }^{33}$ and, above all, the interest of Claudius, who gave orders to perform expiatory rites in the sacred grove of Diana via the pontiffs, as stated by Tacitus, and extended the ancient rule of Servius Tullius to the Diana of the Aventine. ${ }^{34}$ Since the sacred grove in Munigua (see infra) follows the guidelines of the oldest and most relevant sanctuaries in the Lazio region, could the epigraphic reference to Daesa as pontufex nemoris be interpreted as a reflection of this antiquarian policy which was at the time being undertaken in the Vrbs Roma? The Roman province of Baetica has provided other examples of religious antiquarianism which underline the deep Romanisation of the élites. Think, for example, of the Porcuna/Obulco inscription that alludes to the erection of a statue to the scrofa cum porcis triginta, which commemorates Aeneas finding the prodigious sow with its thirty piglets. ${ }^{35}$

An epigraph from Fonni (Cerdeña) mentions a nemus Sorabensis of which Diana and Silvanus are the subject of a dedication by the prefect of the island. ${ }^{36}$ More interesting is a funerary dedication from Aricia/Genzano di Roma to Lucius Antonius Ionicus, member of the sodalitas of the Mars Salutaris youth and quinquennial for

\footnotetext{
${ }^{30}$ See Hofeneder, A.: Die Religion der Kelten in den antiken literarischen Zeugnissen. Band II. Von Cicero bis Florus. Sammlung, Übersetzung und Kommentierung. Wien 2008, 305-311.

${ }^{31}$ The grove may have comprised wild olive trees. As Pliny ( $N H$ III 15) mentions the nearby stipendiary city of Cappa cum Oleastro, it could be understood that this sacred site contained a small number of people living there (due to the affluence of the celebrations in the sacred grove?): this would be an indicator of the importance of the religious activities performed in the lucus during the year or at any specific time therein (FERNÁNDEZ NIETO [n. 10] 541).

32 ABASCAL PALAZÓn, J. M.: Las inscripciones latinas de Santa Lucía del Trampal (Alcuéscar, Cáceres) y el culto a Ataecina en Hispania. AEspA 68 (1995) 31-105; GARCÍA-BELLIDO (n. 9).

${ }^{33}$ See BERNARDI, A.: L'interesse di Caligola per la successione del rex Nemorensis e l'arcaica regalità nel Lazio. Athenaeum 31 (1953) 273-287.

34 Tac. Ann. XII 8: Addidit Claudius sacra ex legibus Tulli regis piaculaque apud lucum Dianae per pontifices danda. See Momigliano, A.: Sul dies natalis del santuario federale di Diana sull'Aventino. In Momigliano, A.: Terzo contributo alla storia degli studi classici e del mondo antico. Roma 1966, 641-648, here 647-648. Claudius and his family entrusted themselves to Diana of Aricia in the inscription: Eph. Ep. 7. 1242 (=ILS 220).

${ }^{35}$ MARCO SIMÓN, F.: El pasado presente. La actualización de los sacra principiorum en una ciudad de la Bética en el s. I d.E. ARYS 4 (2001) 165-180.

${ }^{36} A E$ 1990, $00451=A E$ 1992, 00891; EDCS-05200292: [Di]ana[e et] Silvano / [n]emoris Sorabensis / C(aius) Ulpius Severus / proc(urator) Aug(usti) / praef(ectus) prov(inciae) S[ar(diniae)].
} 
the collegium of the lotores Nemorensium, which is mentioned in another inscription in Aricia (CIL XI 5215). ${ }^{37}$

Nevertheless, the pontufex nemoris from Celti seems to constitute a hapax. The term nemus - less frequent than $l u c u s^{38}$ - appears on 34 inscriptions according to the information from Clauss-Slaby data base. But the most interesting parallel for priests in relation to sacred groves is - in addition to the fratres Arvales or the rex Nemorensis - the flamen lucularis Laurentium Lavinatium testamented in Foligno/Fulginiae (Umbria), ${ }^{39}$ which seems to confirm the existence of a small sacred grove in which the Laurentes Lavinates gathered - a priesthood normally filled by knights, ${ }^{40}$ organised by Claudius in the year 47 to celebrate the $800^{\text {th }}$ anniversary of Rome to which was assigned this lesser flamen, servant of a divinity whose name we ignore.

It is possible that this flamen lucularis was connected to the ritual of the Lucaria, the celebration held in the lucus on Pintia hill, between the Tiber and the Via Salaria (Paul. Fest. 119 M). The Augustan grammarian Verrius Flaccus linked this ritual to the Roman defeat to the Gauls at the battle of Allia. Perhaps this festival should be linked to the ritual of the maintenance of the sacred grove mentioned by Cato (De agr. 139), invoking an anonymous divinity, whose celebration from 19 to 21 July mentions the Fasti Amiterni - datable to the time of Tiberius -, which brought together various well-known laws in Italy (the inscriptions of Lucaria, Spoletum, Narbo Martius and Salona or the Hyginus Gromaticus text). ${ }^{41}$

Trebatius Testa, a lawyer and friend of Cicero, indicated that the luci in the lands conquered by Rome in Italy tended to be maintained in their original sacred condition. This could also be the Hispanic case shown by the Celtiberian inscription from Botorrita/Contrebia Belaisca (Zaragoza), which documents at the beginning of the first century BC a lex sacra that regulated the agricultural use of a sacred oak forest (De Bernardo 2010), which is unsurprising in Celtic environment like that. The

${ }^{37}$ AE 1912, 00092 = AE 1991, 00382; EDCS-1270017: Di\{i\}s Manib(us) / L(ucio) Antonio Ionico / sodali iuvenum / colleg(ii) Mart(is) Salut(aris) / et quinq(uennali) colleg(ii) lot(orum) / Nemorensium quinq(uies?) / Cornelia Thallusa / coniug(i) suo ben(e) mer(enti) f(ecit) / et sibi cum quo vix(it) a(nnos) $X X X$. The lotores Nemorensium are also mentioned on another gravestone in Aricia (CIL XIV 2156). Obscure by nature and under the protection of the Diana of Nemi, the collegium performed an activity connected to the fullones or perhaps a washing service for fabrics and clothing or occasional assistance at the baths (BRUUN, C.: Lotores: Roman Bath-Attendants. ZPE 98 [1993] 222-228).

38 Pasqualini, A.: Lucus. In De Ruggiero, E. (ed.): Dizionario Epigrafico di Antichità Romane IV. Roma 1975, 1969-1989.

${ }^{39}$ CIL XI 05215 = EDCS-22 01157: P(ublio) Aelio P(ubli) f(ilio) Papir(ia) / Marcello cent(urioni) / frum(entariorum) subprincipi $\{$ pe $\}$ / peregrinorum adstato / et principi et pri $<o=I>$ pilo / leg(ionis) VII Gem(inae) Pi(a)e Fel(icis) adlec/to ad munera praeff(ectorum) / legg(ionum) VII Claud(iae) et primae / Adiutricis v(iro) e(gregio) flamini / Luculari Laurent(i) Lavina(ti) / patrono et decurioni co/loni(a)e Apule(n)sium patrono / civitat(ium) Foro Fla(miniensium) Fulginia(tium) / itemque Iguvinorum splen/didissimus ordo Foro Flam(iniensium) / cuius dedicat(ione) decurionibus / et liberis eorum panem / et vinum et HS XX n(ummum) item / municipEckibus HS IIII n(ummum) dedit.

${ }^{40}$ SAULNIER, C.: Laurens Lavinas. Quelques remarques à propos d'un sacerdoce équestre à Rome. Latomus 43 (1984) 517-533.

${ }^{41}$ See Gargola, D. J.: Rome, its Colonies and the Maintenance of a Larger Identity. In JEHNE, M. LINKE, B. - RÜPKE, J. (Hrsg.): Religiöse Vielfalt und soziale Integration. Die Bedeutung der Religion für die kulturelle Identität und politischen Stabilität im republikanischen Italien. Heidelberg 2013, 201-235. 
importance of the grove as a place for key rituals among the Celts is well known. ${ }^{42}$ The quintessential sanctuary is the nemeton, ${ }^{43}$ whose etymology is similar to that of the lucus (sacred clarity within the grove). In other works, ${ }^{44}$ I have analysed the process of individuation of this ritual space, which becomes a deity with a name to be worshipped - something that is documented perfectly in Hispania and ancient Celtic lands in general. ${ }^{45}$ In an inscription in the cave at La Griega in Pedraza, Segovia, in central Spain, there is a votive inscription to Nemedus Augustus, and in Mieres (of the sacred space Asturias) an altar to Nimmedus Aseddiagus is documented. This process of individuation seems to also be ascribed to the Germans by Tacitus: they did not consider it fitting for the gods to be trapped within walls or presented in human form: thus they sanctified groves for them and gave the names of gods to that mysterious something that can only be seen through the eyes of its venerator. ${ }^{46}$

${ }^{42}$ BrunAuX, J. L.: Les bois sacrés des Celtes et des Germains. In Les bois sacrés (n. 4) 57-65; GreEN, M.: Seeing the Wood for the Trees: The Symbolism of Trees and Wood in Ancient Gaul and Britain. Aberyswith 2000; DEMANDT, A.: Der Baumkult der Kelten. In TERNES, CH. M. - ZINSER, H. (Hrsg.): Dieux des Celtes / Götter der Kelten / Gods of the Celts [Études Luxembourgeoises d'Histoire et Sciences des Religions 1]. Luxembourg 2002, 1-18. The term "druid" has been interpreted as "he who is aware through oak", establishing a direct link between this tree and the name for the Celtic priest, and X. DELAMARRE (Dictionnaire de la langue gauloise: Une approche lingüistique du vieux-celtique continental. Paris 2001, 150) explains the term "druids" as "the Experts on the Tree of the World", an etymology that would refer to the myth of the cosmic tree. Another explanation prefers to view the first element dru- as an augmentative prefix: thus, the druids would be the "most wise" or "most prophetic" (LE RoUX, F. GuyOnVarc'H, F.: Les Druides. Rennes 1978, 35-38; BrunauX, J. L.: Les Druides. Des philosophes chez les barbares. Paris 2006, 101). In any case, the link between druids and the woods seems to be upheld by the radical vid-, which also serves to name the tree.

${ }^{43}$ Ancient toponyms such as Augustonemeton (Clermont-Ferrand), Nemetodurum (Nanterre), $\mathrm{Ne}$ metobriga (Ptol. Geog. 2. 6. 36), located in modern day Puebla de Trives in Orense, or ethnonyms such as Nemetati, Gallaecians mentioned by Ptolemy (Geog. 2. 6. 40) in the 2nd century, equally connected to nemeton. See LAMBERT, P.Y.: La langue gauloise. Paris 1989, 85; MARCO SiMÓN, F.: La individuación del espacio sagrado. Testimonios cultuales en el Noroeste hispánico. In MAYER, M. - GÓMEZ PALLARÉS, J.: Religio Deorum. Culto y Socidad en Occidente [Actas del coloquio internacional de epigrafia]. Barcelona 1993, 317-324; and MARCO SIMÓN, F.: Nemedus Augustus. In ADIEGO I. J. ET ALII (eds.): Studia Palaeohispanica et Indogermanica J. Untermann ab amicis Hispanicis oblata. Barcelona 1993, 165-178, with their corresponding references. Equally, Maximus of Tyre (Dissert. 8. 8) stated - at the end of the 2nd century - that oak was the visible representation of the supreme god of the Gauls, assimilating it to the Greek Zeus in a characteristic example of interpretatio.

${ }^{44}$ MARCO SIMÓN: La individuación (n. 43); MARCO SIMÓN: Nemedus Augustus (n. 43).

${ }^{45}$ In theonyms such as Nemetona (the trustee goddess of the Gallic Nemetes and Treveri, linked to Mars), Matres Nemetiales or Mars Rigonemetis attested to in England (JUFER, N. - LÜGINBUHL, T.: Répertoire des dieux gaulois. Les noms des divinités celtiques connus par l'épigraphie, les textes antiques et la toponymie. Paris 2001, 56 and 59).

${ }^{46}$ Tac. Germ. 9: Ceterum nec cohibere parietibus deos neque in ullam humani oris speciem assimulare ex magnitudine caelestium arbitrantur: lucos ac nemora consecrant deorumque nominibus appellant secretum illud, quod sola reverentia vident. Not surprisingly therefore the topic of the "holy tree cutter" became a characteristic element of the Christianization of the indigenous religious systems. This happened with St. Martin of Tours, as recorded by Sulpicius Severus in chapter 13 of his Vita Martini (Vida de San Martín. In Obras completas de Sulpicio Severo. Trad. C. CODOÑER. Madrid 1987, 135-173, here 154-155) and it is shown in the capital of the abbey of St. Mary Magdalene of Vézelay (SANTOS MARINAS, E.: Encuentros y desencuentros en torno a los árboles: el culto a los árboles en las religión eslava precristiana. In CAEROLS, J. J. [ed.]: Religio in labyrintho. Encuentros y desencuentros de religiones en sociedades complejas. Madrid 2013, 111-119, here 114). 


\section{THE TEMPLE OF GABII IN ITALY}

The excavation of the temple at Gabii - probably dedicated to Juno - expressed the systematisation and memorialisation in the Hellenistic period of an ancient grove sanctuary that had persisted in the cavities, excavated in part out of the rock, forming a regular pattern in the space between the triple U-shaped portico and temple itself (which surrounded it), arranged in two consecutive stages (mid-2nd century BC and Sulla era). There is little doubt that such cavities contained trees, hence the Spanish excavators fairly concluded that this was a $\operatorname{lucus}^{47}$ similar to the sacred trees known from diverse sanctuaries in Latium in the areas around the temples and connected to hydraulic installations, such as in the Hercules Victor sanctuary at Tivoli or the nemus Aricinum itself. This was the object of a major reconstruction around $100 \mathrm{BC}$, which recalls the evenness of the trees surrounding the temples mentioned which has been revealed through archaeology ${ }^{48}$ and whose inclusion on coins has already been mentioned, ${ }^{49}$ and the process of monumentalization continued along the first century BC and the Augustan Principate.

This Latium model of a monumentalized ancient grove was exported to the Roman province of Baetica, as shown by the sanctuary at Munigua (ancient Mulva, close by Villanueva del Río, Seville), which can attest to the same circular wells arranged in parallel lines in connection with the hydraulic installations in the western part of the patio. ${ }^{50}$ In this sanctuary-type (with a temple, surrounding treed area and theatre in front), the first feature - the area inaugurated - would be the real lucus, ${ }^{51}$ in line with the definition by Isidore of Seville (locus densis arboribus septus: Orig. 14. 8. 30), a clarity in the midst of the grove, of the nemus. I feel it is important to remember here that the urban development in Munigua of terraces that terminate at the sanctuary begun in the Augustan Principate, and that a tessera records the hospitality agreement between the inhabitants of the city and Augustus himself through his quaestor Sextus Curvius Silvinus. ${ }^{52}$

Just as occurred in other parts of the Empire (particularly in Italy, where we have much better information through documents such as the lex luci Spoletina ${ }^{53}$ ),

${ }^{47}$ Almagro-Gorbea, M.: El santuario de Juno en Gabii. Roma 1982.

${ }^{48}$ COARELli: Munigua (n. 24) 89-90 and 165-185, esp. 171-174; COARELLi: I luci (n. 4) 50-51.

${ }^{49}$ AMPOLO: Boschi sacri (n. 16), 162, fig. 1.

${ }^{50}$ GRÜNHAGEN, W.: El santuario en terrazas de Munigua. In Crónica del V Congreso Nacional de Arqueología, Zaragoza 1957. Zaragoza 1959, 275 ff.; CoARElli, F.: Munigua, Praeneste e Tibur. I modelli laziali di un municipio della Betica, Lucentum 6, 1987, 91-100; COARELLI: I luci (n. 4) 52.

${ }^{51}$ COARELLI: I luci (n. 4) 52.

${ }^{52}$ AE 1962, 147, 287 = AE 1972, 263: Sex(tus) Curvius Silvinus q(uaestor) pro / pr(aetore) hospitium fecit cum senatu / populoque Muniguensi Hispaniae/ ulterioris eosque liberos posteros/que eorum in fidem clientelamque / suam liberorum posterorumque / suorum recepit / egerunt / L(ucius) Lucceius L(uci) f(ilius) mag(istratus) / leg(atus) / L(ucius) Octavius M(arci) f(ilius) Silvanus.

${ }^{53}$ PASCUALini (n. 38); PANCIERA, S.: La lex luci Spoletina e la legislazione sui boschi sacri in età romana. In Monteluco e i monti sacri. Spoleto 1994, 25-46 (= Epigrafi, epigrafia, epigrafisti. Scritti vari editi e inediti [1956-2005] con note complementari e indici. Roma 2006, 903-919). On the rules for trusteeship and capitalizing on the economic resources of the sacred groves by the Greek polis, see DILLON, M. P.: The Ecology of the Greek Sanctuary. ZPE 118 (1997) 113-127. 
there is information in the Iberian Peninsula that allows one to think not just about the existence of the sacred groves, ${ }^{54}$ and even epigraphic documentation that details their regulation. Such would be the case, according to Patrizia de Bernardo, of the Botorrita Bronze, a lex sacra alluding to an oak grove divided into two triangular areas belonging to two divinities, Togotis and Sarnicios (where tree felling, burning or damaging would not be possible) and to Neitos. ${ }^{55}$

Given that it was forbidden to use iron within the sacred groves, it is very possible $^{56}$ that the leges lucorum found at the entrance to the groves would have been housed in a wooden support ${ }^{57}$ - which would explain the scarcity of documentation available on this subject.

While Trebatius Testa, jurist friend of Cicero, indicates that the luci of the territories conquered by Rome in Italy used to be preserved with its original sacral status, ${ }^{58}$ the status of such pre-Roman environments depend on whether the Roman authority included their ancient rituals in the list of public worship in every city, in which case they were affected by the same provisions governing the rest of loca sacra, ie. the public places under the ownership of the gods, among which were evidently the sacred forests. 59

${ }^{54}$ MARCo SIMÓN: La individuación (n. 43); MARCO SIMÓN: Nemedus Augustus (n. 43); FERNÁNDEZ NiETO (n. 10). D. R. SHACKLETON BAILEY (Animals not admitted: Martial 4. 55. 23-24. TAPhA 119 [1989] 285) upholds the hypothesis that animals and, most especially horses, were not permitted in the sacred holm oak grove in Buradón mentioned by Martial (4. 55. 23) (as happened in the Diana Nemorensis grove in Aricia). As for the Diana sanctuary near Segobriga, interpreted as a sacred grove for an ancestral cult, we feel we have argued convincingly that this was a Roman sanctuary in stone (ALFAYÉ Villa, S. - MARCo Simón, F.: Santuarios en canteras y romanización religiosa en Hispania y Gallia. In Mangas Manjarrés, J. - Novillo LóPEZ, M. A. (eds.): Santuarios suburbanos y del territorio en las ciudades romanas. Madrid, 2014, 53-86). It is more likely that the El Trampal (Alcuéscar, Cáceres) sanctuary was a sacred grove: later surveyors named it lucus Feroniae (Agennius Urbicus, de controv. 37. 13; Hyginus "Gromaticus", de limit. 135. 15; 136), in what appears to be a case of interpretatio of the ancestral goddess Ataecina (GARCÍA-BELlido, M ${ }^{\mathrm{a}}$ P.: Las religiones orientales en la Península Ibérica: documentos numismáticos I. AEspA 64 [1991] 37-81, here 69-75; ABASCAL PALAZÓN [n. 32]).

${ }^{55}$ DE BERNARDO STEMPEL (n. 11), an interpretation followed by FERNÁNDEZ NIETO (n. 10). Being forbidden to fell (and also farm or construct), thus set the unequivocal order for the ancient populace that tools could not be used in the lucus, and in the sanctuary entry was sine ferro (unless permission had been granted by the civil-religious authority, or atonement had been performed). Once in the sacred space, the scale of the paths that crossed the grove needed to be preserved, leading to controlled forest conservation. All of this is clearly shown in the regulations that governed, for example, the Dea Dia grove in Italy. However, the Italic lucus at Marica, in Minturnae, was not crossed by paths (it was övodos: Plut. Mar. 37. 9).

${ }^{56}$ FERNÁNDEZ NiETO (n. 10).

${ }^{57}$ ECK, W.: Inschriften auf Holz. Ein unterschätztes Phänomen der epigraphischen Kultur Roms. In KNeIsSL, P. - LosemanN, V. (eds.): Imperium Romanum: Studien zu Geschichte und Rezeption. Festschrift für Karl Christ zum 75. Geburtstag. Stuttgart 1998, 203-217.

${ }^{58}$ Serv. auct. Aen. XI 316: secundum Trebatium, qui de religionibus libro septimo ait luci qui sunt in agris qui concilio capti sunt, hos lucos eadem caerimonia moreque conquiri haberique oportet, ut ceteros lucos qui in antiquo agro sunt.

${ }^{59}$ SCHEID, J.: Sanctuaires et territoire dans la Colonia Augusta Treverorum. In BRUNAUX, J.-L. (éd.): Les sanctuaries celtiques et leur relation avec le monde méditerranéen. Actes du Colloque de St-Riquier (8-11 novembre 1990). Paris 1991, 42-57 here 42; FERNÁNDEZ NIETO (n. 10) 545-546. Surveyors distinguish two types of loca sacra from the legal point of view: those owned by the Roman state that the priestly colleges Romans rented against payment of a vectigal (the sacred land of the priests is mentioned 


\title{
4. CONCLUSION
}

The recreation of the past through real or fictitious revivals of archaic cults is one of the key traits of the Augustan age and it has in the rituals that occurred in the sacred groves and in the creation of priesthoods to deal with them, a vital element in my opinion. The connection of the name of Augustus with the archaic sanctity of the grove is clear - in foundations like the Hispanic Lucus Augusti or in colonies such as the Iulia Felix Lucoferensis which Augustus himself founded in Soracte -, but it also showed itself in the numismatic iconography, as we have seen. There is evidence in the Augustan Principate of very interesting priesthoods such as the pontufex Nemoris in Baetica, on a par with the flamen Lucularis of the Lavinate priests, as well as of the spreading of the Gabii model as architectural monumentalisation of archaic grove sanctuaries, in places such Munigua. All of this inscribes itself within the characteristic tendency of Augustus and his successors towards the updating of the sacra prodigiorum of the origins of the Vrbs as a key tool in the recreation of the Roman identity within a globalised empire.

\author{
Francisco Marco Simón \\ "Hiberus" Research Group \\ University of Zaragoza \\ Pedro Cerbuna, 12 \\ E-50009 Zaragoza
}

\footnotetext{
in Symmach. ep. 1. 68), and sacred sites owned by a city such as the Mons lucus Dianae Iuliensium under the tutelage of the populus of the Colonia Iulia Constantia or as the Celtitanus nemus of Daesa; on these issues, CASTILlo PASCUAL, P.: Las propiedades de los dioses: los loca sacra. Iberia. Revista de la Antigüedad 3 (2000) 100-102. For the urban toponymy as an expression of the development of urban centers around sacred groves (Lucus Asturum, Augusti, etc.), see FERNÁNDEZ NiETO (n. 10) 547.
} 